Open Access

\title{
Family, society and the individual: determinants of entrepreneurial attitudes among youth in Chennai, South India
}

\author{
Radha Jagannathan ${ }^{1 *}$, Michael J. Camasso ${ }^{2}$, Bagavan Das $^{3}$, Jale Tosun ${ }^{4}$ and Sadagopan lyengar ${ }^{5}$
}

\author{
* Correspondence: \\ radha@rutgers.edu \\ ${ }^{1}$ Bloustein School of Planning \& \\ Public Policy, Rutgers, The State \\ University of New Jersey, 33 \\ Livingston Avenue, New Brunswick, \\ NJ 08901, USA \\ Full list of author information is \\ available at the end of the article
}

\begin{abstract}
High rates of youth unemployment across the world have captured the attention of many world organizations and other policy makers. One policy solution that has been proposed to curb these high rates is encouraging youth entrepreneurship. In this paper, we examine the formation of attitudes that are favorable to entrepreneurship using data from 185 business students in South India. We adopt an approach that tests the relative efficacy of two principal factors in the formation of entrepreneurial attitude, i.e., stocks of youth human/social capital and a series of personality traits. Results from a probit model suggest that the youth's prior labor market experience, the social capital that youth have accumulated through volunteering, and the social connections that parents have made are all highly predictive of pro-entrepreneurial attitudes; personality traits exert less importance. Implications for these findings are discussed for the creation of strategies that can stimulate entrepreneurship among youth as one way to combat high rates of youth unemployment.
\end{abstract}

Keywords: Youth entrepreneurship, Social capital, Entrepreneurial inclination, Youth unemployment, Probit regression

\section{Background}

'Scarred generation,' 'lost generation, and 'timepass generation' are but a few monikers given to today's youth, with available data painting a troubling picture of a deepening unemployment crisis among young adults. The problem appears to be truly global in nature and has swept quite indiscriminately through both developed and developing economies. In North Africa and the Middle East, the unemployment crisis has even triggered several episodes of social unrest, commonly referred to as the 'Arab Spring' (Fergusson and Yeates, 2014). According to the International Labor Organization (ILO), there are 1.2 billion people in the 15 -24 age group, representing $40 \%$ of the world's unemployed, with this group's unemployment rate outpacing adult unemployment by nearly three times (ILO, 2012a, b). Rates vary quite widely by region and by countries within a region. For example, while the youth unemployment rate for the European Union is reported at $21.6 \%$ in 2014 by Eurostat, youth unemployment has reached 'alarming levels' (European Commission 2014) in Greece (52.1\%), Spain (52.4\%) and Italy (42.7\%). However, Austria (9.6\%), Germany (7.3\%) and Malta (11.5\%) report much lower unemployment rates (Tosun et al. 2017). Among developing

(c) The Author(s). 2017 Open Access This article is distributed under the terms of the Creative Commons Attribution 4.0 International License (http://creativecommons.org/licenses/by/4.0/), which permits unrestricted use, distribution, and reproduction in any medium, provided you give appropriate credit to the original author(s) and the source, provide a link to the Creative Commons license, and indicate if changes were made. 
economies, North Africa (23.7\%) and the Middle Eastern countries (28.3\%) register the highest rates, and East and South Asian countries record the lowest (9.5 and 9.3\%, respectively). Even though the lower rates of youth unemployment reported in East and South Asian countries may not be 'alarming' by conventional standards, Schmid (2015) points out that it is indeed alarming when one considers the problem from an intergenerational risk-sharing perspective; the Indian youth unemployment rate, for example, is three to four times higher than that of its working age adults.

More generally, high unemployment rates in this age group have resulted in lower youth employment-to-population ratio, which is projected to become even lower in almost all regions of the world by 2018, with the largest decrease of 1.1 to 2.5 percentage points expected to occur in the Asian regions (ILO, 2013). The youth unemployment phenomenon has officially reached crisis proportions, so much so that it has merited a new acronym called NEET (Not in Education, Employment or Training; Eurofound, 2011) and a variant called NLFET (Neither in the Labor Force nor in Education or Training), with a large majority of unemployed youth falling into these categories. Another reason for raising the alarm regarding high levels of youth unemployment when it comes to India, Schmid points out again, is that the percentage of NEET youth in India is one of the highest (28\%) among the G20 countries (Schmid, 2015).

Given the obvious implications of large proportions of unemployed youth for the production of human and economic capital, as well as for increased potential for youthdriven societal unrest, it is not surprising that many international bodies such as the World Bank, the United Nations, the Organization for Economic Cooperation and Development (OECD), and the International Labor Organization have been actively involved in seeking solutions to the youth unemployment crisis. Growing prominence of the problem on the world stage has forced and/or enabled many countries to formulate clear policy agenda and many initiatives to address the challenge. The ILO's Youth Policy Database indicates that 122 out of 198 countries had some version of a national youth policy in 2014, up from 99 countries that had some in the previous year (ILO, 2015).

One prominent approach to engaging the NEET / NLFET youth that is emerging from global discussions, is entrepreneurship (World Bank, 2008; Lukes 2012; ODI, 2012; ILO, 2013; Kew et al., 2013; United Nations, 2013). For example, the Global Entrepreneurship Monitor's (GEM) report on youth unemployment and entrepreneurship states that,

"With the formal sector in many countries experiencing stagnant or slow growth, it is unlikely that this sector will be able to offer work opportunities to the increasing number of young people looking for employment. Unless alternative employment options are encouraged, the number of unemployed, underemployed youths and youth in vulnerable employment will continue to increase. Youth entrepreneurship needs to be enabled, as an additional way of allowing the youth into the labour market and promoting job creation.....The traditional job for life career path has become rarer and youth entrepreneurship will need to be seen as an additional way of allowing the youth into the labour market and promoting job creation." (Kew et al., p.7,9, GEM India Report 2013)

The purpose of this paper is to examine the perceived desirability of entrepreneurship among a fairly diverse group of business students in Chennai, South India. We examine the relative importance of two principal sets of factors, i.e., stocks of youth human/ 
social capital and personality traits that could serve as predictors of the 'entrepreneurial attitude' or the propensity to venture into business startup, self-employment and private sector risk taking behavior. A majority of the studies that have addressed the subject of career choice have focused on one set of these variables, often to the neglect of the other (Hofstede, 1998; Schwartz, 2003). We view the creation of this attitude in much the same way as economists view the production of any productive behavior or attitude, i.e., as a function of work ethic (labor) and resources (capital). The implications of a significant relationship between personality traits and entrepreneurial attitude vis a vis a strong connection between human/social capital and entrepreneurial propensity would seem to have important implications for the manner in which entrepreneurial attitudes are fostered and nurtured.

Our choice of India as the study site is motivated by both availability of recent survey data as well as the intuitive appeal the site offers for the study of youth unemployment problem and its potential solution. India, soon to be the most populous nation in the world, currently boasts one of the largest and the youngest workforce in the world, with $65 \%$ of its population under 35 years of age, and is slated to experience the so called 'demographic dividend.' This demographic advantage is expected to last at least until the middle of this century, and to add $2 \%$ to India's GDP growth rate each year (Government of India, 2013). Young job seekers made up nearly $50 \%$ of the total unemployed population in India but the workerto-population ratio among youth is declining (Saraf and Banerjee, GEM India Report, 2013, p.49). The global economic crisis has severely curbed the high rates of growth that India experienced during the first decade of this century when the GDP growth rate peaked at $9.7 \%$ to around 6\% in 2012 (Sinha, 2013). Additionally, according to the most recent census, India already registers the highest percentage of young people (44\%) living below the poverty line globally (Sinha, 2013).

\section{A brief history of youth entrepreneurship in India}

"The education system has to be designed in a way that produces a large number of employment generators and not just employment seekers," exhorted the visionary exPresident of India and the late, Dr. A. P. J. Abdul Kalam, when he addressed students at India's premier college, the Indian Institute of Technology, Mumbai in 2015. With a large population, a fairly youthful profile, its fair share of intelligence and a generous share of natural resources, one would expect India to be a world-leader in the supply of entrepreneurs. However, this is not the case.

Development of the entrepreneurial spirit in modern India has been rather slow: this can be attributed in a large measure to the centuries of British occupation and the Macaulayian education system that the British introduced in India (Jaffrelot, 1996). The system aimed at producing obedient clerks to serve the interests of the British administration and did hardly anything to encourage creativity or individual enterprise. It is not an exaggeration to say that independent thinking in all fields, including the economic sphere, was actively discouraged by the British-a striking example is their successful attempt to put down with an iron hand the nascent shipping line promoted by Sri V.O. Chidambaram Pillai and rewarding him with rigorous imprisonment for having dared to display enterprise (Padmanabhan, 2001). 
In contrast, the much-maligned caste system that prevailed in ancient and medieval India, (as codified by the Manu Smriti and other seminal works), provided for a specific class of people, the Vysyas, whose duty it was to engage in industry and trade. By providing that whoever was born in that caste should adopt the hereditary occupation, society ensured that entrepreneurship was in the cultural makeup of every person in that social group, leading them to imbibe, innovate and excel at enterprise. The widespread existence of industry and of youthful entrepreneurship in the eighth century and earlier too, is recorded by Azhwars (poetic saints of South India) in their works collectively known as Divya Prabandam. One such account graphically portrays smoke billowing out of canecrushing activity in villages, the precursor of the modern sugar mills, centuries before the Industrial Revolution (Thirumangai Azhwar, circa 776). Evidence of world recognition of medieval Indian entrepreneurship is also provided by the demand for Indian muslin cloth that was used in wrapping Egyptian mummies (Manimala et al., GEM India 2001 report, p.8). It is quite ironic that it is this kind of entrepreneurial expertise that brought colonial powers (English, Dutch, Portuguese and the French) to India.

The British system of education introduced in India thus produced generations of students whose outlook was conservative and whose preference was for service (and preferably government service) as a provider of economic stability. Creative thinking and the spirit of striking out for oneself were conspicuous by their absence in the curriculum. Added to this, the post-colonial License Raj characterized by its ubiquitous webs of bureaucratic red-tape ushered in by the socialist policies of the newly independent nation placed virtually insurmountable hurdles in the path of anyone daring to display entrepreneurial ambitions. Thus, if the country continued to figure in the list of developing nations, without signs of graduating to the level of a developed one, it could well be attributed to a lack of widespread entrepreneurial effort. In the early 1990s and thereafter (popularly referred to as Jugad Raj and Invisible Raj), however, the Indian government shifted fundamentally away from socialistic policies and toward market-led economic development policies, opening up trade and investment, introducing deregulation, tax reforms, and inflation controls. Within a decade, these policies propelled India's economic stature globally, touting historically high growth rates, with India becoming better and better known for information and communication technology. Economic reform in India began in right earnest in 1991 when the government embraced the goal of establishing a more market-oriented economy and expanded the role of private and foreign investment. Specific reform measures included the reduction in import tariffs, the deregulation of markets, tax reductions, and an increased attractiveness for foreign investment (see, e.g., Ravallion 2009).

Rates of entrepreneurship also saw corresponding increase. In 2001, the GEM India survey of about 2000 adults showed that the level of entrepreneurial activity in India was $11.2 \%$, and that younger people were much more likely to be engaged in entrepreneurial activities than older people. Although India had pivoted significantly by this time from the notion of entrepreneurship by birth to entrepreneurship creation, substantial roadblocks to success still remain. For example, analysis of responses from experts on the same GEM survey cited above found that while India scored better than the average of 29 countries surveyed on entrepreneurial capacity and commercial and professional infrastructure, it scored below average on many of the enabling conditions for entrepreneurship such as government policies, physical infrastructure, education 
system, R\&D transfer, and respect for entrepreneurship in the society (Manimala et al., GEM India Report 2001). These findings were largely confirmed by the second iteration of the survey a year later, although entrepreneurial activities had increased to nearly 18\% (Manimala, GEM India Report 2002). The latest survey conducted in 2013 concludes that the lack of credible legal frameworks, stable political structures and strategic factor markets continue to inhibit entrepreneurial activities, that have by now dipped to about 10\% (Saraf and Banerjee, GEM India Report 2013). Taken together, the GEM surveys indicate that even though great strides were made in the 1990s and 2000 s with respect to entrepreneurship, so much so that $63 \%$ of Indian youth now viewed it as a desirable career choice, a much more entrepreneur-friendly environment needs to be in place through institution building efforts and more conducive government policies (Saraf and Banerjee, GEM India Report 2013).

\section{Conceptual considerations and relevant literature}

We derive our conceptual guidance from the theory of reasoned action/planned behavior (Ajzen and Fishbein 1980; Fishbein and Ajzen, 1975; Ajzen 1991; Ajzen 2002; for an application to entrepreneurship, see Warmuth et al. 2014) that generally posits that behavioral choices are rationally made, and are preceded by intentionality toward the behavior which in turn is influenced by the individual's attitudes (favorable or unfavorable perceptions) toward the behavior. These attitudes themselves may be determined by the different sets of values, beliefs, and personality traits that individuals may acquire through socialization, or inherit from their family (see, e.g., Carr and Sequeira 2007).

In this paper, we adopt a variant of the reasoned action framework and use the conceptual model that appears as Fig. 1. Here, we confine our interest to the formation of entrepreneurial attitudes, which are thought to be an important determinant of entrepreneurial intention, subsequently leading to engagement in entrepreneurship. This approach is necessary here because of the nature of the study sample, i.e., graduate level business students, whose entrepreneurial intentions and behaviors are yet to be observed. The literature on entrepreneurship also empirically demonstrates the link between attitudes and entrepreneurship behavior (Krueger \& Carsrud, 1993; Lee, Chua and Chen, 2004; Goel, Zhang, and Arora, 2007). In addition, we posit that parental

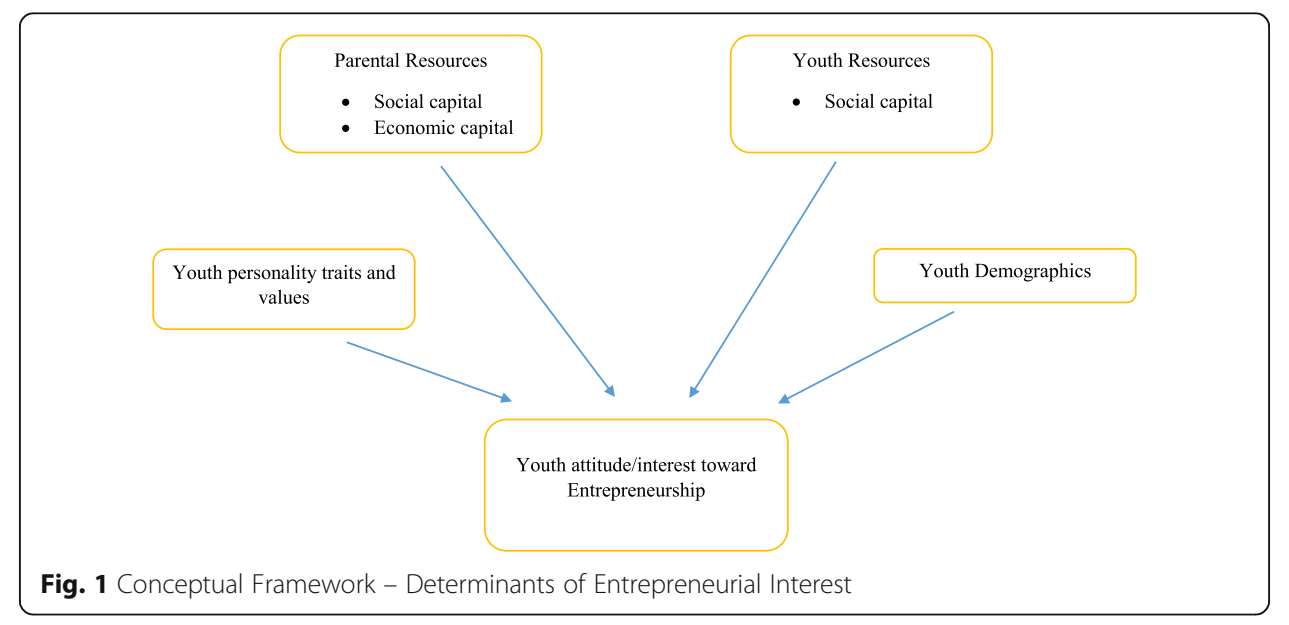


social and economic capital, youth's values, beliefs, and personality traits, youth's stock of social capital all directly and collectively influence the youth's attitude toward entrepreneurship (see Warmuth et al. 2014). While we recognize that the youths' stock of social and cultural capital in their various forms may be derived in part from their parents or the family in general, we do not model this process because of data constraints. Specifically, we do not have direct information from the parents/family that sheds light on the transmission or the transmission processes that occur when values, beliefs and other forms of capital are passed on intergenerationally.

\section{Determinants of pro-entrepreneurial attitude}

Family capital Parental or familial capital in the form of finances and social connections have been shown to significantly influence attitudes toward entrepreneurship and actual entrepreneurship behavior. This is particularly true when considering students engaged in higher education, when career choices are foremost in their minds (Gelderen et al. 2008; Leffel and Darling, 2009). In the context of developing countries, parental financial resources become all the more important in shaping entrepreneurial attitudes of these students, since most of them partially or wholly depend on their families for educational and other needed support (Sharma, 2014). For example, the GEM 2013 survey indicates that in sub-Saharan Africa, a little over three quarters of new or nascent entrepreneurs rely primarily on their families and friends for startup funding (Kew et al., GEM India Report 2013).

The family's social capital in its various forms are also thought to be critical in inculcating an entrepreneurial mindset. Systematically developed by scholars over the years (Lin et al., 1981; Bourdieu, 1983; Coleman, 1988; Putnam, 2000) the notion of social capital refers to the networks of relationships that individuals create that have the potential for mutual benefits; and much like economic capital, is capable of producing returns. It is therefore conceivable that youth who are exposed to family connections, especially those with some entrepreneurial content, may reap benefits from such connections and develop positive inclinations toward entrepreneurship. In India, such connections have the promise of helping negotiate a vast bureaucracy and/or procuring startup funding that are a pre-requisite for any business establishment.

Individual capital The amount of education and other related skills the youth has acquired, (human capital), their economic resources, and the network of personal connections he/she has made (social capital) can be thought to influence entrepreneurial attitudes. Since the stock of human capital can more or less be presumed to be constant in our study population (all are graduate students), and all have more or less no individual income, we focus here on the youth's social capital. The amount of social capital acquired and accumulated by the youth is hypothesized to influence their attitude toward entrepreneurship. The ability to extract benefits from their contacts fulfils any shortfalls youth may experience in their access to information, capital or skills necessary for a business venture (Aldrich and Zimmer, 1986; Aldrich et al., 1991; Hansen, 1995). Network contacts may provide new or different ideas and world views that broaden the opportunity framework for new ventures (Aldrich and Zimmer, 1986; Aldrich et al., 1998; Freitag, 2006; Maloney and Rossteutscher, 2007; Bonaventura and Caserta, 2012). Having role models and other friends who are entrepreneurs are reported to be correlated with higher entrepreneurial inclination (Collins \& Moore, 1970; Cooper \& Dunkelberg, 1984; Davidsson 
and Honig, 2003; Mahadea et al., 2011; Sharma \& Madan, 2014). An integral component of social capital is trust, which often results from mutual obligations and exchanges or a threat of censure (Coleman, 1988; Granovetter, 1985; Putnam, 1993), and forms the basis for ties that hold individuals and organizations together (Davidsson and Honig, 2003).

Personality traits such as creativity, innovativeness, leadership capability, independence, non-conformity, risk taking or fear of failure, and need for achievement, are often cited to be indicators of interest in entrepreneurial activities (McClelland, 1961; Krueger, 2009; Sorenson and Chang, 2006; Saraf and Bannerjee, 2013; Lukeš and Zouhar, 2013). Empirical support for this relationship, however, has been mixed, depending on the discipline, the particular set of traits studied, and setting of the study (Henderson \& Robertson, 2000; see Sorenson and Chang, 2006 for a detailed review). An individual's values, i.e., enduring motivations, are also thought to guide, justify, or explain attitudes and through attitudes, subsequent behaviors (e.g., Halman and de Moor, 1994; Rokeach, 1973; Schwartz, 1992; Williams, 1968).

Demographic characteristics Gender has received some attention as a possible predictor of entrepreneurial attitude and behavior (Strohmeyer and Tonoyan 2005). It is generally believed that males are significantly more inclined toward entrepreneurship, although the empirical evidence is far less settled on the issue. There appear to be nearly as many studies that find significant gender differences in entrepreneurial interest, attitudes, and behavior (Shinnar et al., 2012; Yardanova and Tarrazon, 2010; Kickul et al., 2008; El Harbi, et al., 2009; Asos et al., 2007) as those that do not (Maxfield et al., 2010; Wilson et al., 2007; Veciano et al., 2005; Kourilskva and Walstadb, 1998). Moreover, even when gender differences are found, they have been shown to be culture-sensitive (Shinnar et al., 2012; Strobl et al., 2012).

Having prior work experience can be expected to enhance an individual's interest in entrepreneurship since it provides an opportunity to observe the workings of the labor market, to learn valuable work ethic, and to expand their network of contacts. There appears to be some empirical support for this view (Ghazali et al., 1995; Kristiansen and Indarti, 2004; Othman et al., 2006; Keat et al., 2011).

The long-entwined links between religion and the caste system in India are also thought to have economic connections, especially to entrepreneurial inclination and behavior. Economists including Adam Smith and Max Weber have pointed to this connection (Audretsch et al., 2007), where the latter argued that the caste system has a negative effect on the economy. Hindus are the religious majority in India ${ }^{1}$ and given the proscription of material pursuits advocated by Hinduism, a clear delineation of occupations based on castes, and the perpetuation of occupational decisions over generations, it is conceivable that religion influences the propensity to become an entrepreneur. In fact, a study of 90,000 workers in India revealed that while some religions (Islam and Christianity) were conducive to entrepreneurship, others, such as Hinduism were highly inhibitive (Audretsch et al., 2007).

\section{Empirical studies on youth entrepreneurship in South India}

In a comparative study of attitudes of college students towards entrepreneurship in China and India, Goel and his colleagues found significant regional differences among Indian youth. Youth in South India were particularly more likely to report that 
entrepreneurship is better than working for others, is more rewarding, is deserving of societal respect, and to emphasize the necessity of entrepreneurship in making the country prosperous, than youth from other regions (Goel et al., 2007). There have been a few studies of a more descriptive nature conducted in South India, especially in Tamil Nadu, with smaller samples using correlational techniques. These studies find that family income, parental history of business ownership (Rathika, 2012; Tamizharasi and Panchanatham, 2010; Jayalakshmi and Saranya, 2015; Manivannan et al., 2013), availability of entrepreneurial opportunities (Kavitha, 2014), education, marital status, and business type (Palaniappan et al., 2012), gender (Jayalakshmi and Saranya, 2015; Sankar and Sutha, 2016), previous work experience (Khan, 2015; Jayalakshmi and Saranya, 2015), and personality traits such as risk taking, self-control, self-confidence, innovativeness, independence, achievement oriented, enthusiasm, self-motivation, and ability to influence others (Manivannan et al., 2013; Kundu and Rani, 2007; Thavaraj, 2014) are highly correlated with entrepreneurial interest and inclination.

\section{Methods}

Sample

The study sample comes from the first year MBA students from four colleges in Chennai, the capital of Tamil Nadu in South India, the fifth largest city, and the fourth largest metropolitan area in the country, and considered a 'melting pot' of cultures exhibiting tremendous diversity that is representative of South Indian cities. It should also be noted that the Institute for Career Studies calls Tamil Nadu as "India's higher education hub," boasting the highest number of universities in India (Institute for Career Studies, 2012). The Times of India, the oldest English language daily newspaper in India and the largest selling daily newspaper (English) in the world, lists Tamil Nadu as one of top 5 academic destinations for students in India (The Times of India, 2016). Our choice of college students majoring in business studies as the appropriate target of study is quite deliberate insofar as these students represent the pool from which future entrepreneurs are drawn and are often the focus of entrepreneurship education (Zeffane, 2013; Goel et al., 2007). The appropriateness of such a sample, especially of business students, also finds much justification in the extant literature (Shinnar et al., 2012; Strobl et al., 2012; Kickul et al., 2008; Yordanova and Tarrazon, 2010; Gupta et al., 2009).

A two-stage sampling plan was used to select the study participants. In the first stage, four schools (SRM University, Vellammal Engineering College, Crescent University, and Loyola Institution of Business Applications) were randomly selected using a probability proportion to size method from a pool of thirteen ranked business schools. In the second stage a complete enumeration method was adopted by contacting the first year graduates of the four selected schools. All four schools were private universities, and two schools (Loyola and Crescent) had a religious affiliation. This sampling scheme yielded a total of 209 students, who responded to an extensive survey that gleaned information on their interest and attitudes toward entrepreneurship, stocks of social and cultural capital, personality traits, values and beliefs, and general world view. The survey was pre-tested in during the summer of 2014 and was finalized in September 2014. Data were collected from students in 
a group setting over a 4 month period (October 2014 - January 2015). The data cleaning process yielded a useable dataset of 185 observations with non-missing values on the analysis variables.

\section{Variable measures}

Dependent variable

The dependent variable in the analysis (Entrepreneur_Attitude), entrepreneurial interest or attitude, is the response to questions regarding the prestige in owning a business or being one's own boss. A very high percentage of students (81\%) in this sample considered entrepreneurship to be desirable. Such high levels of interest are not uncommon - for example, the GEM India survey (Saraf and Bannerjee, GEM India Report, 2013) found that nearly $75 \%$ of youth assigned a positive social status to being an entrepreneur, and considered it a desirable career choice.

\section{Independent variables}

Family capital: We create a composite dummy variable called Parent_contacts which captures the individual's access to parents' social networks, coded as ' 1 ' when parents have substantial contacts with their friends and neighbors, and ' 0 ' otherwise. The family's economic capital (Household_income) is measured by the net household monthly income on an 8-point ordinal scale with less than INR 25000 to INR 55000 or more. Family capital is expected to exert a positive influence on attitudes toward entrepreneurship.

Youth social capital: Our measures of the individual's social capital comprise indicators of trust, information on their social networks including volunteer activities, contacts with friends and neighbors, and connections to entrepreneurs. One measure of trust we employ is derived from the 28-item Rotter's Interpersonal Trust Scale (Rotter, 1967). Following the approach taken by Wright and Tedeschie (1975) and conducting our own factor analysis, we form three sub-scales: Political trust (trust of politicians and the media), Paternal_trust (trust of benign authorities like parents, experts, publicopinion poll respondents, etc.), Stranger_trust (trust of anonymous others such as strangers, the honor system, etc.). The response scale on these items are recoded in order for higher scores to consistently represent more trust. We also use two other indicators of trust: General_trust, which is a response to a well-established trust question scored on a scale of 0 to 10, often used in the European Social Survey that asks whether most people can be trusted. In addition, we use a measure of the student's confidence in the Indian political system by summing responses to questions on trust at the central, state and local levels (Indian _ political trust) with higher scores reflecting higher levels of trust or confidence. As other indicators of youth social capital: we measure their active membership in two types of volunteer organizations: Volunteer_education (education, art, or music) and Volunteer _ professional (professional organizations); frequency of their contact with friends and neighbors (Social_contacts) ranging from once a month or less (1) to daily (4); and finally the percentage of close friends who are entrepreneurs (Friends_entrepreneurs), a dummy variable, coded as 1 indicating more than $25 \%$ of friends who are entrepreneurs and a 0 otherwise. We hypothesize that except for trust or confidence in the political system, other forms of trust, as well as youth's social networks positively affect entrepreneurial interest and attitudes. 
Youth personality traits and values: Our primary source for this group of measures is the Portrait Values Questionnaire ${ }^{2}$ developed by Shalom Schwartz, one that is widely used in many European national surveys. Following Schwartz (2003), we create ten separate subscales reflecting benevolence, universalism, self-direction, stimulation, hedonism, achievement, power, security, conformity and tradition, calculate the mean of items that index each subscale, center the subscale mean by subtracting the overall mean (of 21 items) from it, and use nine of the ten subscales in our analyses to avoid multicollinearity (Universalism, Self-direction, Stimulation, Hedonism, Achievement, Power, Security, Conformity, and Tradition). ${ }^{3}$ Innovation, a trait that is particularly emphasized in the entrepreneurship literature, is captured by two of these subscales self-direction and stimulation - comprising items such as "Thinking up new ideas, and being creative and original is important to her/him," She/he likes surprises and is always looking for new and different things to do in life," and "She/he looks for adventure, likes to take risks, and wants to have an exciting life." Traits or values regarding self-direction, stimulation, achievement and power are clearly expected to be positively related to entrepreneurial attitudes, while those related to universalism, conformity, security and tradition, may be negatively related.

We measure risk taking (Risk_taker) as a composite of five dichotomous responses ( 1 = yes, $0=$ no) to the following items: (a) park in 'no parking' zones when no other spaces are available, (b) make risky job changes, (c) recommend that friends and family take risks in their careers, (d) play the lottery very often, and (e) encourage children to play contact sports like soccer, football and boxing. We expect higher levels of risktaking to be predictive of entrepreneurial attitudes.

Demographic variables: We include three variables in this category - work experience, religiosity, and gender. Work_experience is measured as a dummy variable with ' 1 ' indicating prior work experience, and ' 0 ' indicating none. Religiosity (Religious_attendance) is the frequency of attendance at religious services measured on a scale of 1 to 7 , with ' 1 ' = never and ' 7 ' = more than once a week. Gender is a dummy variable with ' 1 ' indicating males and ' 0 ', females. We expect males and those individuals with previous work experience to be positively inclined toward entrepreneurship, while religion may inhibit such an inclination.

In addition to the variables described above, we also include indicators of students' institutional affiliations captured by three dummy variables, using the institution with the largest proportion of students (SRM University) as the reference group.

The distribution of all study variables is shown in Table 1 . About $40 \%$ of the students in the study sample were from the two religious institutions (Crescent University and Loyola University), and the other 60\% came from secular institutions (Vellamal Engineering College and SRM University). Fifty-seven percent of the students was male, with $32 \%$ of all students reporting some kind of prior work experience. Family income averaged about INR 45000, with nearly $60 \%$ of the parents having strong social connections with friends and neighbors. Sample youth generally reported high levels of trust, with the exception of trust in the Indian political system. Fifty-four percent of the youth engaged in volunteering in education or art related activities, with a fourth being active volunteers in professional organizations. Their contacts with friends and neighbors averaged between once a week and few times a month, and nearly a quarter of them had friends who were entrepreneurs. Levels of risk taking in the sample was quite high, 6.1 on a 10 point scale. Measures of personality traits and values exhibited tremendous variability. 
Table 1 Distribution of study variables, $n=185$

\begin{tabular}{|c|c|c|c|c|}
\hline Variable Name & Mean & Standard deviation & Minimum & Maximum \\
\hline \multicolumn{5}{|l|}{ Dependent variable } \\
\hline Entrepreneur_attitude & 0.810811 & 0.3927217 & 0 & 1 \\
\hline \multicolumn{5}{|l|}{ Independent variables: } \\
\hline \multicolumn{5}{|l|}{ Family Capital } \\
\hline Parent_contacts & 0.59459 & 0.4923027 & 0 & 1 \\
\hline Household_income & 5.372973 & 2.74779 & 1 & 8 \\
\hline \multicolumn{5}{|l|}{ Youth social capital } \\
\hline Political_trust & 11.35135 & 2.887531 & 5 & 18 \\
\hline Paternal_trust & 19.83784 & 2.964587 & 12 & 26 \\
\hline Stranger_trust & 9.659459 & 1.921766 & 6 & 14 \\
\hline General_trust & 5.481081 & 2.338459 & 0 & 10 \\
\hline Indian_political trust & 9.259459 & 3.36021 & 4 & 16 \\
\hline Volunteer_education & 0.535135 & 0.5001175 & 0 & 1 \\
\hline Volunteer_professional & 0.27027 & 0.4453045 & 0 & 1 \\
\hline Social_contacts & 2.405405 & 1.017762 & 1 & 4 \\
\hline Friends_entrepreneurs & 0.25946 & 0.4395276 & 0 & 1 \\
\hline \multicolumn{5}{|l|}{ Personality traits/Values } \\
\hline Universalism & 0.367568 & 0.6517046 & -2.42857 & 2.047619 \\
\hline Hedonism & -0.88108 & 1.019656 & -3.76191 & 1.952381 \\
\hline Self-direction & 0.297297 & 0.767389 & -2.61905 & 1.952381 \\
\hline Stimulation & 0.189189 & 0.9002788 & -3.11905 & 2.214286 \\
\hline Achievement & 0.151351 & 0.7535868 & -1.90476 & 2.047619 \\
\hline Security & -0.06216 & 0.7921345 & -2.59524 & 1.857143 \\
\hline Power & -0.47297 & 0.9084654 & -3.30952 & 1.857143 \\
\hline Conformity & -0.21081 & 0.9017724 & -3.45238 & 1.476191 \\
\hline Tradition & -0.01351 & 0.8335725 & -2.7381 & 1.857143 \\
\hline Risk_taker & 6.102703 & 1.878148 & 0 & 10 \\
\hline \multicolumn{5}{|l|}{ Demographic } \\
\hline Work_experience & 0.313514 & 0.4651801 & 0 & 1 \\
\hline Religious_attendance & 4.454054 & 1.887976 & 1 & 7 \\
\hline Male & 0.572973 & 0.4959886 & 0 & 1 \\
\hline \multicolumn{5}{|l|}{ University } \\
\hline Crescent University & 0.194595 & 0.3969626 & 0 & 1 \\
\hline Loyola Institution of Business Application & 0.216216 & 0.4127805 & 0 & 1 \\
\hline Velammal Engineering College & 0.248649 & 0.4334026 & 0 & 1 \\
\hline SRM University & 0.340540 & 0.475177 & 0 & 1 \\
\hline
\end{tabular}

\section{Analytic strategy}

The dichotomous nature of the dependent variable leads us to estimate probit regression models to examine the effect of various groups of variables on youth's entrepreneurial interest. We first define a continuous latent variable $I_{i}$, that denotes an individual's entrepreneurial interest as a function of conceptually relevant characteristics: 


$$
\mathrm{I}_{\mathrm{i}}=\lambda_{1} \mathrm{FC}_{\mathrm{i}}+\lambda_{2} \mathrm{YSC}_{\mathrm{i}}+\lambda_{3} \mathrm{YPTV}_{\mathrm{i}}+\lambda_{4} \mathrm{DEMO}_{\mathrm{i}}+\lambda_{5} \mathrm{UNIFIX}+\mathrm{e}_{\mathrm{i}}
$$

where $i$ subscripts denote individuals; FC denotes a vector of variables pertaining to family or parental capital, YSC contains a vector of variables measuring youth social capital, YPTV is a vector of youth personality traits and values, DEMO includes a series of demographic variables, UNIFIX contains university fixed effects, $\lambda_{1}-\lambda_{5}$ are vectors of regression coefficients, and e is an identically and independently normally distributed error term, with mean zero and variance $\sigma^{2}$ (which may be normalized to unity without loss of generality). We assume that an individual's attitude towards entrepreneurship is positive if and only if $I_{i}>0$. Set the binary indicator variable $D_{i}$ equal to unity (zero) if the youth expresses a positive attitude (does not express a positive attitude) for individual i, then

$$
\begin{aligned}
\operatorname{Pr}\left\{\mathrm{D}_{\mathrm{i}}\right. & \left.=1 \mid \mathrm{FC}_{\mathrm{i}}, \mathrm{YSC}_{\mathrm{i}}, \mathrm{YPTV}_{\mathrm{i}}, \text { DEMO }_{\mathrm{i}}, \mathrm{UNIFIX}\right\} \\
& =\operatorname{Pr}\left\{\mathrm{I}_{\mathrm{i}}>0 \mid \mathrm{FC}_{\mathrm{i}}, \mathrm{YSC}_{\mathrm{i}}, \mathrm{YPTV}_{\mathrm{i}}, \text { DEMO }_{\mathrm{i}}, \text { UNIFIX }\right\} \\
& =\operatorname{Pr}\left\{\mathrm{e}_{\mathrm{i}}>-\mathrm{Z}_{\mathrm{i}} \mid \mathrm{FC}_{\mathrm{i}}, \mathrm{YSC}_{\mathrm{i}}, \text { YPTV }_{\mathrm{i}}, \text { DEMO }_{\mathrm{i}}, \text { UNIFIX }\right\}
\end{aligned}
$$

where $\mathrm{Z}_{\mathrm{i}}=\lambda_{1} \mathrm{FC}_{\mathrm{i}}+\lambda_{2} \mathrm{YSC}_{\mathrm{i}}+\lambda_{3} \mathrm{YPTV}_{\mathrm{i}}+\lambda_{3} \mathrm{DEMO}_{\mathrm{i}}+\lambda_{3}$ UNIFIX.

Under the assumption that the error term e is normally distributed, the loglikelihood of a sample of individuals' entrepreneurial attitudes is given by

$$
\log \ell=\mathrm{D}_{\mathrm{i}} \log \left\{1-\Phi\left(-\mathrm{Z}_{\mathrm{i}}\right)\right\}+\left(1-\mathrm{D}_{\mathrm{i}}\right) \log \left\{\Phi\left(-\mathrm{Z}_{\mathrm{i}}\right)\right\}
$$

where $\Phi()$ is the standard normal cumulative density function. We estimate the parameters of the model by maximizing (2) with respect to these parameters.

We follow a sequential modeling approach and estimate five models: the first model only uses family capital to predict pro-entrepreneurial attitude; Models 2, 3 and 4 incrementally add measures of youth's social capital, personality traits and values, and demographics; and finally Model 5 includes university-specific indicator variables (fixed effects) that control for unmeasured, time-invariant differences across the four universities. For all five models, we calculate Huber-White standard errors that provide robustness against heteroscedasticity.

\section{Results}

Table 2 presents probit regression results from the five estimated models. Model fit statistics (Likelihood ratio Wald test and pseudo- $\mathrm{R}^{2}$ ) indicate that all five models have significant predictive power, which increases as additional blocks of variables are included in the model. Significant changes in coefficients across models indicate that earlier models (Models 1-4) may suffer from specification/omitted variables bias. We therefore adopt Model 5, which contains all of the theoretically relevant variables as our final model for further interpretation.

As expected, stocks of family social and economic capital are significantly related to increased probabilities of positive attitudes toward entrepreneurship among youth. Their own stocks of social capital in its various forms of trust, except trust in politics and political systems, are similarly influential in promoting positive attitudes. The social networks they create when volunteering in educational or professional spheres or when connecting with friends and neighbors are also predictive of positive entrepreneurial attitudes. Personality traits or values relating to achievement and power, as well as the willingness to take risks, significantly stimulate interest in entrepreneurship. As expected, individuals who have had 
Table 2 Probit regression results for entrepreneurial attitude, $n=185$

\begin{tabular}{|c|c|c|c|c|c|}
\hline Regressor & Model 1 & Model 2 & Model 3 & Model 4 & Model 5 \\
\hline \multicolumn{6}{|l|}{ Family capital } \\
\hline \multirow[t]{2}{*}{ Parent_contacts } & $0.572^{* *}$ & $0.573^{* *}$ & $0.565^{* *}$ & $0.466^{*}$ & $0.926^{* * *}$ \\
\hline & $(2.39)$ & $(2.12)$ & $(2.06)$ & $(1.70)$ & $(2.79)$ \\
\hline \multirow[t]{2}{*}{ Household_income } & -0.0182 & 0.00563 & 0.0153 & 0.0164 & $0.108^{*}$ \\
\hline & $(-0.46)$ & $(0.13)$ & $(0.32)$ & $(0.34)$ & $(1.86)$ \\
\hline \multicolumn{6}{|l|}{ Youth social capital } \\
\hline \multirow[t]{2}{*}{ Political_trust } & & $-0.0811^{*}$ & $-0.0995^{* *}$ & $-0.103^{* *}$ & $-0.209^{* * *}$ \\
\hline & & $(-1.84)$ & $(-2.20)$ & $(-2.33)$ & $(-3.23)$ \\
\hline \multirow[t]{2}{*}{ Paternal_trust } & & 0.0652 & $0.0816^{*}$ & $0.0818^{*}$ & $0.144^{* * *}$ \\
\hline & & $(1.44)$ & $(1.91)$ & $(1.92)$ & (3.05) \\
\hline \multirow[t]{2}{*}{ Stranger_trust } & & $0.141^{* *}$ & $0.208^{* *}$ & $0.218^{* * *}$ & $0.313^{* * *}$ \\
\hline & & $(2.22)$ & (3.18) & (3.33) & (3.49) \\
\hline \multirow[t]{2}{*}{ General_trust } & & 0.0187 & 0.0471 & 0.0560 & $0.122^{*}$ \\
\hline & & $(0.35)$ & $(0.76)$ & $(0.90)$ & $(1.70)$ \\
\hline \multirow[t]{2}{*}{ Indian_political trust } & & -0.00293 & -0.0335 & -0.0395 & $-0.086^{*}$ \\
\hline & & $(-0.09)$ & $(-0.87)$ & $(-1.03)$ & $(-1.77)$ \\
\hline \multirow[t]{2}{*}{ Volunteer_education } & & $0.478^{* *}$ & $0.432^{*}$ & $0.440^{*}$ & $0.941^{* * *}$ \\
\hline & & $(2.16)$ & $(1.83)$ & $(1.91)$ & $(2.96)$ \\
\hline \multirow[t]{2}{*}{ Volunteer_professional } & & 0.485 & $0.555^{*}$ & $0.565^{*}$ & $0.807^{*}$ \\
\hline & & $(1.62)$ & $(1.68)$ & $(1.67)$ & $(1.89)$ \\
\hline \multirow[t]{2}{*}{ Social_contacts } & & $0.309^{* *}$ & $0.312^{* *}$ & $0.307^{* *}$ & $0.570^{* * *}$ \\
\hline & & $(2.90)$ & $(2.66)$ & $(2.60)$ & $(3.81)$ \\
\hline \multirow[t]{2}{*}{ Friends_entrepreneurs } & & -0.234 & -0.249 & -0.256 & -0.231 \\
\hline & & $(-0.89)$ & $(-0.88)$ & $(-0.92)$ & $(-0.74)$ \\
\hline \multicolumn{6}{|l|}{ Personality traits/values } \\
\hline \multirow[t]{2}{*}{ Universalism } & & & 0.180 & 0.201 & 0.152 \\
\hline & & & $(0.57)$ & $(0.65)$ & $(0.39)$ \\
\hline \multirow[t]{2}{*}{ Hedonism } & & & 0.147 & 0.171 & 0.207 \\
\hline & & & $(0.74)$ & $(0.87)$ & $(0.85)$ \\
\hline \multirow[t]{2}{*}{ Self-direction } & & & 0.206 & 0.210 & 0.322 \\
\hline & & & $(0.94)$ & $(0.96)$ & (1.13) \\
\hline \multirow[t]{2}{*}{ Stimulation } & & & 0.155 & 0.197 & 0.328 \\
\hline & & & $(0.74)$ & $(0.92)$ & $(1.14)$ \\
\hline \multirow[t]{2}{*}{ Achievement } & & & 0.186 & 0.209 & $0.570^{* *}$ \\
\hline & & & $(0.84)$ & $(0.97)$ & (1.94) \\
\hline \multirow[t]{2}{*}{ Security } & & & 0.354 & $0.373^{*}$ & 0.358 \\
\hline & & & $(1.63)$ & $(1.70)$ & $(1.45)$ \\
\hline \multirow[t]{2}{*}{ Power } & & & $0.354^{*}$ & $0.392^{*}$ & $0.638^{* * *}$ \\
\hline & & & $(1.75)$ & $(1.87)$ & $(2.71)$ \\
\hline \multirow[t]{2}{*}{ Conformity } & & & -0.104 & -0.105 & -0.307 \\
\hline & & & $(-0.49)$ & $(-0.50)$ & $(-1.10)$ \\
\hline \multirow[t]{2}{*}{ Tradition } & & & 0.205 & 0.219 & 0.249 \\
\hline & & & $(0.86)$ & $(0.92)$ & $(0.85)$ \\
\hline
\end{tabular}


Table 2 Probit regression results for entrepreneurial attitude, $n=185$ (Continued)

\begin{tabular}{|c|c|c|c|c|c|}
\hline \multirow[t]{2}{*}{ Risk_taker } & & & 0.105 & $0.112^{*}$ & $0.177^{* *}$ \\
\hline & & & $(1.63)$ & $(1.66)$ & $(2.05)$ \\
\hline \multicolumn{6}{|l|}{ Demographics } \\
\hline \multirow[t]{2}{*}{ Work_experience } & & & & -0.157 & $0.909^{*}$ \\
\hline & & & & $(-0.63)$ & $(1.62)$ \\
\hline \multirow[t]{2}{*}{ Religious_attendance } & & & & -0.0667 & -0.112 \\
\hline & & & & $(-0.96)$ & $(-1.47)$ \\
\hline \multirow[t]{2}{*}{ Male } & & & & -0.283 & -0.283 \\
\hline & & & & $(-0.65)$ & $(-0.65)$ \\
\hline University fixed effects & No & No & No & No & Yes \\
\hline \multirow[t]{2}{*}{ Constant } & $1.353^{* * *}$ & -1.495 & $-2.618^{*}$ & $-2.402^{*}$ & $-5.531^{* * *}$ \\
\hline & $(4.30)$ & $(-1.13)$ & $(-1.92)$ & $(-1.76)$ & $(-3.32)$ \\
\hline $\begin{array}{l}\text { Overall model fit } \\
(p \text {-value for Wald test) }\end{array}$ & 0.058 & 0.0005 & 0.0022 & 0.0043 & 0.0003 \\
\hline Psuedo R-Squared & 0.03 & 0.16 & 0.22 & 0.23 & 0.41 \\
\hline
\end{tabular}

Note: $\mathrm{t}$ statistics in parentheses.

${ }^{*} p<0.10{ }^{*} p<0.05 * * * 0.01$

prior labor market experience are more inclined towards entrepreneurship. However, engaging in religious activities does not have a significant effect - although the coefficient is in the expected direction, it is imprecisely estimated. The effect of gender is neither significant, nor is it in the predicted direction.

Since probit coefficients represent linear changes in the standardized, continuous dependent variable, they do not have an intuitive or straightforward interpretation on the probability of entrepreneurial interest. It is more useful to use the coefficients to calculate the change in the probability for a small change in the independent variable, i.e., marginal effects of each variable on the probability of interest in entrepreneurship. In Table 3, we present average marginal effects for each regressor using Stata's margins command. These average marginal effects are computed by calculating the change in the probability of entrepreneurial interest due to a change in each variable for each individual using the individual's observed values for all the independent variables, and averaging it over all the individuals. The Table also presents statistical significance of the marginal effects along with a 95\% confidence interval for the effects.

Having a family with substantial social capital increases the youth's probability of entrepreneurial interest by nearly $14 \%$. While the family's economic capital also increases this probability, the marginal effect is quite small, about $1.6 \%$ increase for every INR 5000 increase in the family income.

Among measures of the youth's stock of social capital, establishing social/professional networks through volunteering in educational and professional activities increases their probability of having a favorable entrepreneurial attitude by 14 and $12 \%$, respectively. Increased frequency of contacts with friends and neighbors contributes to a $9 \%$ increase in this probability. While the ability to trust (generally by about $2 \%$ and of strangers, by about 5\%) increases the probability of a favorable entrepreneurial attitude, placing higher levels of trust in the political system decreases this probability (generally by about $3 \%$ and specifically in the Indian political system, by $1.3 \%$ ). 
Table 3 Average marginal effects after Probit for Model 5

\begin{tabular}{|c|c|c|c|c|c|c|}
\hline Regressor & $\begin{array}{l}\text { Marginal effect } \\
\text { (dy/dx) }\end{array}$ & $\begin{array}{l}\text { Delta-method } \\
\text { Std. Err. }\end{array}$ & z & $P>|z|$ & [95\% Conf. & Interval] \\
\hline \multicolumn{7}{|l|}{ Family capital } \\
\hline Parent_contacts & 0.1392051 & 0.0499143 & 2.79 & 0.005 & 0.0413749 & 0.2370353 \\
\hline Household_income & 0.0161006 & 0.0086605 & 1.86 & 0.063 & -0.0008737 & 0.0330749 \\
\hline \multicolumn{7}{|l|}{ Youth social capital } \\
\hline Political_trust & -0.032742 & 0.0092711 & -3.53 & 0 & -0.050913 & -0.014571 \\
\hline Paternal_trust & 0.0219923 & 0.0071733 & 3.07 & 0.002 & 0.0079329 & 0.0360516 \\
\hline Stranger_trust & 0.0486274 & 0.012488 & 3.89 & 0 & 0.0241514 & 0.0731033 \\
\hline General_trust & 0.0177535 & 0.0104912 & 1.69 & 0.091 & -0.0028089 & 0.0383159 \\
\hline Indian_political trust & -0.0126176 & 0.0071117 & -1.77 & 0.076 & -0.0265562 & 0.001321 \\
\hline Volunteer_education & 0.1426186 & 0.0479111 & 2.98 & 0.003 & 0.0487146 & 0.2365227 \\
\hline Volunteer_professional & 0.1222408 & 0.0629303 & 1.94 & 0.052 & -0.0011004 & 0.2455819 \\
\hline Social_contacts & 0.0895546 & 0.0228206 & 3.92 & 0 & 0.044827 & 0.1342822 \\
\hline Friends_entrepreneurs & -0.0344783 & 0.0472705 & -0.73 & 0.466 & -0.1271267 & 0.0581702 \\
\hline \multicolumn{7}{|l|}{ Personality traits/values } \\
\hline Universalism & 0.0179207 & 0.0604408 & 0.3 & 0.767 & -0.1005411 & 0.1363824 \\
\hline Hedonism & 0.0274467 & 0.0374007 & 0.73 & 0.463 & -0.0458574 & 0.1007507 \\
\hline Self-direction & 0.0427031 & 0.0419864 & 1.02 & 0.309 & -0.0395887 & 0.124995 \\
\hline Stimulation & 0.0482096 & 0.0439413 & 1.1 & 0.273 & -0.0379138 & 0.1343331 \\
\hline Achievement & 0.0802865 & 0.0426872 & 1.88 & 0.06 & -0.0033789 & 0.1639519 \\
\hline Security & 0.0547923 & 0.0375486 & 1.46 & 0.145 & -0.0188017 & 0.1283863 \\
\hline Power & 0.0955426 & 0.0338118 & 2.83 & 0.005 & 0.0292728 & 0.1618125 \\
\hline Conformity & -0.050535 & 0.0440738 & -1.15 & 0.252 & -0.136918 & 0.0358481 \\
\hline Tradition & 0.0365672 & 0.045133 & 0.81 & 0.418 & -0.0518918 & 0.1250263 \\
\hline Risk_taker & 0.0260216 & 0.012388 & 2.1 & 0.036 & 0.0017416 & 0.0503016 \\
\hline \multicolumn{7}{|l|}{ Demographics } \\
\hline Work_experience & 0.1473522 & 0.0878582 & 1.68 & 0.094 & -0.0248466 & 0.319551 \\
\hline Religious_attendance & -0.0173703 & 0.0117955 & -1.47 & 0.141 & -0.0404891 & 0.0057485 \\
\hline Male & -0.0087804 & 0.0458508 & -0.19 & 0.848 & -0.0986462 & 0.0810855 \\
\hline \multicolumn{7}{|l|}{ University fixed effects } \\
\hline Crescent University & 0.4081755 & 0.0827803 & 4.93 & 0 & 0.2459291 & 0.5704219 \\
\hline Loyola Inst. Business & 0.0973052 & 0.0903166 & 1.08 & 0.281 & -0.079712 & 0.2743225 \\
\hline Velammal Eng. College & 0.3560661 & 0.0658716 & 5.41 & 0 & 0.2269601 & 0.4851721 \\
\hline
\end{tabular}

Traits and values that are achievement or power oriented have the potential to increase the probability of entrepreneurial interest by about 8 to $10 \%$, and individuals who are more inclined to be risk-taking experience a $2.6 \%$ increase in this probability.

We can expect the individual's prior work experience to translate into a $14 \%$ increase in the probability of considering entrepreneurship as a career choice. Compared to SRM University, business students in Crescent University and Velammal Engineering College have a $41 \%$ and $36 \%$ respectively, higher probability of a positive entrepreneurial attitude. 


\section{Discussion and conclusion}

\section{Study implications and policy recommendations}

This research provides some suggestive, albeit preliminary insights into the relative importance of the factors which signal a proclivity to entrepreneurship. Our findings are congruent with the theoretical framework presented in Fig. 1. Our empirical analyses reveal that parental resources, youth resources, the traits and values that characterize the sample youth, and several demographic factors all have a significant role to play in influencing entrepreneurial interest. However, our most significant results indicate that both the parents' and the youth's stocks of social capital play a particularly crucial role in the formation of entrepreneurial attitudes and interest among youth, and this is also strengthened if the youth had previously engaged in the labor market. Personality traits and values oriented toward achievement and power rank a close second and show that they too have an important role to play in the development of entrepreneurial proclivity. A summary of significant effects appears in Table 4 ranked by the magnitude of their marginal impact on entrepreneurial mindset.

Our findings indicate that connections matter. Youth with stronger or more substantial social networks that they themselves create or those that they have access to through their parents evince stronger interest in entrepreneurship. This is not completely surprising inasmuch as it is these connections that the youth will count on to negotiate government bureaucracies for obtaining permits and the financial system for procuring start-up funding. In addition to providing non-pecuniary emotional support, such connections may also yield a qualified, supportive, and trustworthy mentors or staff for a business enterprise. The importance of social capital for a number of general developmental, economic, and social outcomes is indeed well documented (Aldrich \& Zimmer, 1986; Aldrich et al., 1998; Freitag 2006; Maloney and Rossteutscher 2007). Its importance for entrepreneurial outcomes is supported by many empirical studies as well (Collins and Moore, 1970; Cooper \& Dunkelberg, 1984; Davidsson and Honig, 2003; Mahadea et al., 2011; Sharma and Madan, 2014). This finding provides support for policy measures that increase an individual's connections while still in education, such as encouragement of volunteer opportunities in the educational or professional sectors or other community service opportunities.

Table 4 Ranking of the top 10 statistically significant marginal effects

\begin{tabular}{lll} 
& Marginal & Variable \\
Regressor & Effect & Grouping \\
\hline Work_experience & 0.1473 & Demographic \\
Volunteer_education & 0.1426 & Youth social capital \\
Parent_contacts & 0.1392 & Family capital \\
Volunteer_professional & 0.1222 & Youth social capital \\
Power & 0.0955 & Personality traits/values \\
Social_contacts & 0.0896 & Youth social capital \\
Stranger_trust & 0.0486 & Youth social capital \\
Political_trust & -0.0327 & Youth social capital \\
Risk_taker & 0.0260 & Personality traits/values \\
Paternal_trust & 0.0220 & Youth social capital \\
\hline
\end{tabular}


Prior experience in the labor market, again, not surprisingly, whets entrepreneurial interest. A host of hard and soft skills are learned through employment: in addition to general skills acquired through formal education, when youth enter the labor market, they also develop skills specific to the industry, as well as other 'soft' skills necessary for economic success, viz., skills that develop their ability to take constructive criticism, teamwork, dependability, trustworthiness, and grit (Heckman et al., 2006; Carneiro and Heckman, 2003).

The finding that prior labor market attachment stimulates interest in future labor force participation is hardly new, and has been noted in research on dislocated workers, welfare-to-work recipients, and high school dropouts (Riccio and Orenstein, 1996; Jagannathan and Camasso, 2005). What is new here is the finding that prior work experience can exert a positive influence on the propensity to work for oneself. One implication of this finding is for the design of work and apprenticeship policies while students are still in high school or early years of college. Such an introduction to various career training opportunities and providing a 'taste' for actual participation in a variety of occupations may well stimulate individual interest in entrepreneurship.

Our study shows that some personality traits and values also have a role to play in predicting entrepreneurial inclination. Using data from GEM project, Arenius and Minniti (2005) also find evidence for the importance of 'perceptual variables' such as having confidence in one's own skills and ability or the propensity to take risks in predicting nascent entrepreneurship in all the 28 countries studied. These researchers make a strong case for including perceptual variables in the model, not only for their ability to improve statistical model fit, but arguing that "Entrepreneurship is, after all, about people and, not surprisingly, subjective and often biased perceptions emerge as being highly correlated to nascent entrepreneurship." (p.243).

The data also show that while the capacity of youth to trust in benign societal entities and strangers is important in their development of pro-entrepreneurial attitudes, it is also the case that the young people in this sample believe that elected officials, the media, and the Indian political system at various levels inhibit entrepreneurial interest. Introduction by the government of innovative and transparent public management practices, as well as taking serious measures to curb corruption and perceptions of corruption will go a long way towards building trust with the young population.

Our findings indicate that a strategy that focuses on building social capital is more likely to result in the formation of the entrepreneurial attitude. Education and training that focuses on interpersonal relationships more than personal characteristics and traits would appear to offer a more promising pathway to entrepreneurship. This is not to say that personality is not important, only that it is far from sufficient, at least in the data on hand.

\section{Study limitations}

Our study makes an important contribution to the literature by including two principal sets of factors - stocks of youth human/social capital and personality traits - in predicting entrepreneurial proclivity of college students, and by empirically assessing their relative importance in developing this propensity. However, our study has a number of limitations. First, the fact that parents were not directly queried about their stocks of social and economic capital and that student assessments of these were used as proxy 
measures opens our paper to criticisms of behavioral expectation bias, social desirability bias, or social acquiescence bias. Second, the sample is confined to students from private colleges, who probably have more social capital at their disposal than other college students or non-college young adults. In addition, although we have made efforts to make the colleges studied representative of business students in Chennai, it is possible that the study sample differed in other, unobservable ways from the population of business students in Chennai or Tamil Nadu. It should also be noted ${ }^{4}$ that while the variables used to predict entrepreneurial proclivity in this study follow from a careful reading of the literature, it is still possible that these variables may not reflect characteristics and traits of actual entrepreneurs in Chennai. One possible way to remedy this shortcoming and to empirically validate the study variables would have been to ascertain what attitudes and values characterize actual entrepreneurs in Chennai, and what motivated them to become an entrepreneur. Based on personal interviews with 147 entrepreneurs in six major Indian cities (Chennai, Pune, Kolkata, Ahmedabad, Hyderabad, and Bangalore), the Indian National Knowledge Commission (NKC) found that these entrepreneurs possessed many of the characteristics and traits we have used in this study (e.g., social and family networks, risk tolerance, power, achievement orientation, stimulation or challenge, self-direction, work experience) (Goswami et al., 2008). However, the NKC also acknowledges that not all entrepreneurs generally conform to a particular set of traits or characteristics, citing a Harvard Business School study that avers that "if one could only discern the psychological profile of an entrepreneur and then hold an individual up against that profile, one could predict whether that individual has the potential to become an entrepreneur, or is one already. Yet none of the proposed "profiles" applies to all entrepreneurs, and many entrepreneurs refuse to conform to any of these profiles" (Stevenson and Amabile, 1999; Goswami et al., 2008). Finally, since it is abundantly clear in India, the United States, and elsewhere that college is not a necessary condition for engaging in entrepreneurship, and in some cases may even act as a deterrent, this study may overestimate the importance of social capital and underplay the significance of personality traits.

\section{Endnotes}

${ }^{1}$ According to the 2001 Census, the religious composition of India comprised 81\% Hindus, about $13 \%$ Muslims, and $2.4 \%$ Christians, followed by very small proportions of other religions, viz., Sikhism, Jainism, Buddhism (Premi, 2004).

2"The PVQ is a list of short verbal portraits, with each statement describing "a person's goals, aspirations, or wishes that point implicitly to the importance of a single value type" (Schwartz, 2003). Each item is measured on a scale of 1 to 5 , and when reversed, scores how much the individual identifies with the portrait item. For example: "Thinking up new ideas and being creative is important to him. He likes to do things in his own original way" describes a person for whom self-direction values are important. "Being very successful is important to her/him, along with gaining recognition for her/ his achievements" describes a person who is achievement-oriented.

${ }^{3}$ The subscales and items that index each subscale are available from the authors.

${ }^{4}$ The authors gratefully acknowledge the contributions of Anonymous Referee \#1 regarding this point. 


\section{Additional files}

Additional file 1: Data File. (XLSX $26 \mathrm{~kb}$ )

Additional file 2: Table A1: Schwartz Portrait Values Questionnaire (PVQ) - Subscales and items. (DOCX 18 kb)

\section{Abbreviations}

GDP: Gross Domestic Product; GEM: Global Entrepreneurship Monitor; ILO: International Labor Organization; MBA: Masters in Business Administration; NEET: Not in Education, Employment or Training; NLFET: Neither in the Labor Force nor in Education or Training; OECD: Organization for Economic Cooperation and Development

\section{Acknowledgements}

The authors wish to thank the anonymous reviewers and seminar participants at CEREQ, Marseille, France for their constructive suggestions for improvements to the manuscript.

\section{Funding}

This study was funded by the Centers for Global Advancement and International Affairs at Rutgers University.

\section{Availability of data and materials}

The dataset that supports the analyses and conclusions drawn in the manuscript is attached to the manuscript as Additional files 1 and 2 .

\section{Authors' contributions}

The lead author was in charge of producing the first draft including the conceptual arguments and relevant literature. The second author participated in the empirical analyses and its write up. The third author was in charge of sampling, data collection, and the respective write up. The fourth author produced additional literature and contributed to the discussion section. The fifth author contributed to the section on the history of entrepreneurship in India. All authors read and approved the final manuscript.

\section{Authors' information}

The first four authors are conducting a 4-year youth unemployment study in 10-European nations funded by the European Commission and aim to present a cohesive policy solution to curb high youth unemployment rates that can be implemented not only in Europe, but in other countries facing similar problems.

\section{Competing interests}

The authors declare that they have no competing interests.

\section{Author details}

${ }^{1}$ Bloustein School of Planning \& Public Policy, Rutgers, The State University of New Jersey, 33 Livingston Avenue, New Brunswick, NJ 08901, USA. ${ }^{2}$ Department of Agricultural Food \& Resource Economics, Rutgers, The State University of New Jersey, New Brunswick, NJ 08901, USA. ${ }^{3}$ School of Public Health, SRM University, Chennai, India. ${ }^{4}$ Political Science Department, Heidelberg University, Heidelberg, Germany. ${ }^{5}$ Bank of India (Retired), Editor, Nrisimha Priya Journal, Chennai, India.

Received: 2 November 2016 Accepted: 17 May 2017

Published online: 21 June 2017

\section{References}

Ajzen, I. (1991). The theory of planned behavior. Organizational Behavior and Human Decision Processes, 50(2), 179-211.

Ajzen, I. (2002). Perceived behavioral control, self-efficacy, locus of control, and the theory of planned behavior. Journal of Applied Social Psychology, 32(4), 665-683.

Ajzen, I. \& Fishbein, M. (1980): Understanding attitudes and predicting social behavior. Englewood Cliffs: Prentice-Hall.

Aldrich, H., Birley, S., Dubini, P., Greve, A., Johannisson, B., Reese, P. R., Sakano, T. (1991). The generic entrepreneur? Insights from a multinational research project. April: Paper presented at the Babson Conference on Entrepreneurship.

Aldrich, H., Renzuli, L. A., \& Langton, N. (1998). Passing on privilege: Resources provided by self-employed parents to their self-employed children. Research in Social Stratification and Mobility, 16, 291-317.

Aldrich, H., \& Zimmer, C. (1986). Entrepreneurship through social networks. In D. Sexton \& R. Smiler (Eds.), The art and science of entrepreneurship (pp. 3-23). New York: Ballinger.

Arenius, P., \& Minniti, M. (2005). Perceptual variables and nascent entrepreneurship. Small Business Economics, 24, 233-247.

Asos, G. A., Bruyneel, S., \& Carter, S. (2007). Gender differences in entrepreneurial intentions and business start up activities. Frontiers of Entrepreneurship Research, 27(8), 237-246.

Audretsch, D. B., Boente, W., \& Tamvada, J. P. (2007). Religion and entrepreneurship. C.E.P.R. Discussion papers. London, England: Center for Economic Policy Research.

Bonaventura, L., \& Caserta, M. (2012). The social dimension of entrepreneurship: The role of regional social effects. Entrepreneurship Research Journal, 2(3), 1-18.

Bourdieu, P. (1983). The forms of capital. In J. Richardson (Ed.), Handbook of theory and research for the sociology of education (pp. 241-258). New York: Greenwood Press.

Carneiro, P., \& Heckman, J. (2003). Human capital policy. In J. J. Heckman \& A. B. Krueger (Eds.), Inequality in America: What role for human capital policies? Cambridge, Massachusetts: The MIT Press. 
Carr, J. C., \& Sequeira, J. M. (2007). Prior family business exposure as intergenerational influence and entrepreneurial intent: A theory of planned behavior approach. Journal of Business Research, 60(10), 1090-1098.

Coleman, J. (1988). Social capital in the creation of human capital. American Journal of Sociology, 94, S95-S120.

Collins, O., \& Moore, D. (1970). The organization makers: A behavioral study of independent entrepreneurs. New York: Meredith.

Cooper, A. C., \& Dunkelberg, W. C. (1984). Entrepreneurship and paths to business ownership. In Paper 846, Krannert Graduate School of Management. West Lafayette: Purdue University.

Davidsson, P., \& Honig, B. (2003). The role of social and human capital among nascent entrepreneurs. Journal of Business Venturing, 18(3), 301-331.

El Harbi, S., Anderson, A., \& Naima, M. (2009). The attractiveness of entrepreneurship for females and males in a developing Arab muslim country: Tunisia. International Business Research, 2(3), 46-53.

Eurofound. (2011). Young people and NEETs in Europe: First findings (résumé) European foundation for the improvement of living and working conditions. Dublin: Eurofound.

European Commission (2014). Speech by President Barroso. Youth guarantee: making it happen. http://europa.eu/rapid/ press-release_SPEECH-14-304_en.htm. Accessed 12 Oct 2016.

Fergusson, R., \& Yeates, N. (2014). International governmental organisations and global youth unemployment: The normative and ideational foundations of policy discourses. Policy \& Politics, 42(3), 439-458.

Fishbein, M., \& Ajzen, I. (1975). Belief, attitude, intention, and behavior: An introduction to theory and research. Reading: Addison-Wesley.

Freitag, M. (2006). Bowling the state back in: Political institutions and the creation of social capital. European Journal of Political Research, 45(1), 123-152.

Gelderen, M., Brand, M., Praag, M., Bodewes, W., Poutsam, E., \& Gils, A. (2008). Explaining entrepreneurial intentions by means of theory of planned behavior. Career Development International, 13(6), 538-559.

Ghazali, A., Ghosh, B. C., \& Tay, R. S. T. (1995). The determinants of self-employment choice among university graduates in Singapore. International Journal of Management, 12(1), 26-35.

Goel, A., Vohra, N., Zhang, L., \& Arora, B. (2007). Attitudes of the youth towards entrepreneurs and entrepreneurship: A cross-cultural comparison of India and China. Journal of Asia Entrepreneurship and Sustainability, 3(1), 29-63.

Goswami, A., Dalmia, N., Pradhan, M. (2008). Entrepreneurship in India: A study by National Knowledge Commission. URL: http//knowledgecommissionarchive.nic.in/downloads/documents/NKC_Entrepreneurship.pdf. Accessed 28 Jan 2017.

Government of India. (2013). Report on youth employment-unemployment scenario 2012-2013. Ministry of Labour and Employment. Chandigarh: Labour Bureau.

Granovetter, M. (1985). Economic action and social structure: The problem of embeddedness. American Journal of Sociology, 91(3), 481-510.

Gupta, V. K., Turban, D. B., Wasti, S. A., \& Sikdar, A. (2009). The role of gender stereotypes in perceptions of entrepreneurs and intentions to become an entrepreneur. Entrepreneurship Theory and Practice, 33(2), 397-417.

Halman, L., \& de Moor, R. (1994). Religion, churches, and moral values. In P. Ester, L. Halman, \& R. de Moor (Eds.), The individualizing society (pp. 37-66). Tilburg: Tilburg University Press.

Hansen, E. L. (1995). Entrepreneurial network and new organization growth. Entrepreneurship: Theory \& Practice, 19(4), 7-19.

Heckman, J., Stixrud, J., \& Urzúa, S. (2006). The effects of cognitive and noncognitive abilities on labor market outcomes and social behavior. Journal of Labor Economics, 24(3), 411-482.

Henderson, R., \& Robertson, M. (2000). Who wants to be an entrepreneur? Young adult attitudes to entrepreneurship as a career. Career Development International, 5(6), 279-287.

Hofstede, G. (1998). Attitudes, values and organizational culture: Disentangling the concepts. Organizational Studies, 19, 477-493. Institute for Career Studies. (2012). Tamil Nadu: India's higher education hub. ICS newsletter, June 2012. Lucknow: ICS International.

International Labor Organization (ILO). (2012a). The youth unemployment crisis: Time for action. Geneva: International Labor Office URL: http://www.lo.org/ilc/LCSessions/101stSession/reports/reports-submitted/WCMS_175421/lang-fr/index.htm.

International Labor Organization (ILO). (2012b). Global employment trends for youth 2012. Geneva: International Labor Office URL: http://www.lo.org/wcmsp5/groups/public/—dgreports/—dcomm/documents/publication/wcms_180976.pdf.

International Labor Organization (ILO). (2013). Global employment trends for youth 2013: A generation at risk. Geneva: International Labor Office URL http:/www.lo.org/wcmsp5/groups/public/—dgreports/—dcomm/documents/ publication/wcms_212423.pdf.

International Labor Organization (ILO). (2015). Global employment trends for youth 2015: Scaling up investments in decent jobs for youth. Geneva: International Labor Office URL: http://www.lo.org/wcmsp5/groups/public/—dgreports/— dcomm/—publ/documents/publication/wcms_412015.pdf.

Jaffrelot, C. (1996). Hindu nationalist movement and Indian politics:1925 to the 1990s. New York: Viking Press.

Jagannathan, R., \& Camasso, M. J. (2005). Beyond intention to treat analysis in welfare-to-work studies: The efficacy of labor force attachment, human capital investment and combined strategies for self-sufficiency. Journal of Social Service Research, 31, 43-60

Jayalakshmi, P., \& Saranya, A. S. (2015). Entrepreneurial intention among students of arts and science colleges in Chennai - An empirical study. International Journal on Information Sciences and Computing, 9, 6-15.

Kavitha, G. (2014). Attitude of youth towards entrepreneurship - An exploratory study among the college students in Coimbatore District. Zenith International Journal of Multidisciplinary Research, 4, 170-180.

Keat, O. Y., Selvarajah, C., \& Meyer, D. (2011). Inclination towards entrepreneurship among university students: An empirical study of Malaysian university students. International Journal of Business and Social Science, 2(4), 206-220.

Kew, J., Herrington, M., Litovsky, Y., Gale, H. (2013). Generation entrepreneur? The state of global youth entrepreneurship. London: The Prince's Youth International Business \& Global Entrepreneurship Monitor Report

Khan, F. R. (2015). Women entrepreneurship in Chennai, India - Factors trigger and prevent. International Journal of Management, Innovation \& Entrepreneurial Research, 1, 29-43.

Kickul, J., Wilson, F., Marlino, D., \& Barbosa, S. D. (2008). Are misalignments of perceptions and self-efficacy causing gender gaps in entrepreneurial intentions among our nation's teens? Journal of Small Business and Enterprise Development, 15(2), 321-335. 
Kourilskva, M., \& Walstadb, W. B. (1998). Entrepreneurship and female youth: Knowledge, attitudes, gender differences, and educational practices. Journal of Business Venturing, 13(1), 77-88.

Kristiansen, S., \& Indarti, N. (2004). Entrepreneurial intention among Indonesian and Norwegian students. Journal of Enterprising Culture, 12(1), 55-78.

Krueger, N. F. (2009). Entrepreneurial intentions are dead: Long live entrepreneurial intentions. In A. L. Carsrud \& M. Brannback (Eds.), Understanding the entrepreneurial mind (pp. 51-72). New York: Springer.

Krueger, N. F., \& Carsrud, A. L. (1993). Entrepreneurial intentions: Applying the theory of planned behavior. Entrepreneurship \& Regional Development, 5(4), 315-330.

Kundu, S. C., \& Rani, S. (2007). Personality and attitudes of Indian young female workforce: Entrepreneurial orientation by education and regions. Managing Global Transitions, 5, 229-252.

Lee, L., Chua, B. L., \& Chen, J. (2004). Antecedents for entrepreneurial propensity and intention: Findings from Singapore, Taiwan, and Hong Kong (working paper). Singapore: National University of Singapore Entrepreneurship Centre.

Leffel, A., \& Darling, J. (2009). Entrepreneurial versus organizational employment preferences: A comparative study of European and American respondents. Journal of Entrepreneurship Education, 12, 79-91.

Lin, N., Ensel, W. M., \& Vaughn, J. C. (1981). Social resources and strength of ties: Structural factors in occupational status attainment. American Sociological Review, 46(4), 393-405.

Lukeš, M. (2012). Supporting entrepreneurial behavior and innovation in organizations. Central European Business Review, 2, 29-36.

Lukeš, M., \& Zouhar, J. (2013). No experience? No problem - it's all about yourself: Factors influencing nascent entrepreneurship outcomes. Ekonomický časopis, 61(9), 934-950.

Mahadea, D., Ramroop, S., \& Zewotir, T. (2011). Assessing entrepreneurship perceptions of high school learners in Pietermaritzburg, KwaZulu-Natal. South African Journal of Economic and Management Sciences, 14(1), 66-79.

Maloney, W. A., \& Rossteutscher, S. (2007). Assessing the significance of associational concerns: Leisure, politics and markets, in W.A. Maloney and S. Rossteutscher (Eds.) Social capital and associations in European democracies: A comparative analysis (pp. 52-78). Abingdon: Routledge.

Manimala, M. J. (2002). Global entrepreneurship monitor India report 2002. Bangalore: Indian Institute of Management.

Manimala, M. J., Prakhya, S., Gopal, M. V., \& Shields, J. (2001). Global entrepreneurship monitor India report 2001. Bangalore: Indian Institute of Management.

Manivannan, K., Dath, T. N. S., \& Uma Maheswari, S. D. (2013). Mediating effect of personality traits on attitude towards entrepreneurship. In National Conference on "entrepreneurship in India - Road ahead" 20 march 2013. Nadu: University of Madras and Government of Tamil.

Maxfield, S., Shapiro, M., Vipin, G., \& Hass, S. (2010). Gender and risk: women, risk taking and risk aversion. Gender in Management: An International Journal, 25(7), 586-604.

McClelland, D. C. (1961). The achieving society. Princeton: Van Nostrand.

Othman, M. N., Ghazali, E., \& Cheng, O. C. (2006). Demographics and personal characteristics of urban Malaysian entrepreneurs: An ethnic comparison. International Journal of Entrepreneurship and Innovation Management, 5(5/6), 421-440.

Padmanabhan, R. A. (2001). Doyen of Swadeshi Shipping. The Hindu, 22 September 2001.

Palaniappan, G., Ramanigopal, G. S., \& Mani, A. (2012). A study on problem and prospects of women entrepreneurs with special reference to Erode District. International Journal of Physical and Social Sciences, 2, 219-230.

Putnam, R. D. (1993). Making democracy work: Civic traditions in modern Italy. Princeton: Princeton University Press.

Putnam, R. D. (2000). Bowling alone: The collapse and revival of American community. New York: Simon \& Schuster.

Rathika, V. (2012). Inclination of entrepreneurship among MBA women students in Namakkal District, Tamil Nadu. Namex International Journal of Management Research, 2, 112-118.

Ravallion, M. (2009). A comparative perspective on poverty reduction in Brazil, China and India. World Bank Policy Research Working Paper Series, Vol.

Riccio, J. A., \& Orenstein, A. (1996). Understanding best practices for operating welfare-to- work programs. Evaluation Review, 20, 3-28.

Rokeach, M. (1973). The nature of human values. New York: Free Press.

Rotter, J. B. (1967). A new scale for the measurement of interpersonal trust. Journal of Personality, 35, 651-665.

Sankar, P., \& Sutha, I. (2016). College student mindset and intentions toward entrepreneurship in Chennai City. International Journal of Research - Granthalaya, 4, 36-39.

Saraf, N., \& Banerjee, B. (2013). Global entrepreneurship monitor 2013: India Report. Ghaziabad: Institute of Management Technology.

Schmid, G. (2015). Youth unemployment in India: From a European and transitional labour market point of view. IZA Policy Paper No. 95. IZA, Bonn, Germany.

Schwartz, S. H. (1992). Universals in the content and structure of values: Theory and empirical tests in 20 countries. In M. Zanna (Ed.), Advances in experimental social psychology (Vol. 25) (pp. 1-65). New York: Academic Press.

Schwartz, S. (2003). A Proposal for measuring value orientations across nations. Questionnaire Development Package of the European Social Survey (Chapter 7) (pp. 259-319). European Social Survey.

Sharma, L. (2014). Impact of family capital \& social capital on youth entrepreneurship - A study of Uttarakhand state in India. Journal of Global Entrepreneurship Research, 4(14), 1-18.

Sharma, L., \& Madan, P. (2014). Effect of individual factors on youth entrepreneurship - A study of Uttarakhand state, India. Journal of Global Entrepreneurship Research, 2(3), 1-17.

Shinnar, R. S., Giacomin, O., \& Janssen, F. (2012). Entrepreneurial perceptions and intentions: The role of gender and culture. Entrepreneurship Theory and Practice, 36(3), 465-493.

Sinha, P. (2013). Combating youth unemployment in India. New Delhi: Friedrich-Ebert-Stiftung.

Sorensen, J. B., \& Chang, P. M. Y. (2006). Determinants of successful entrepreneurship: A review of the recent literature. Report prepared for the Ewing Marion Kauffman Foundation. Cambridge: MIT Sloan School of Management.

Stevenson, H. H., \& Amabile, T. M. (1999). Entrepreneurial management: In pursuit of opportunity. In T. K. McCraw \& J. L. Cruikshank (Eds.), The intellectual venture capitalist: John H. McArthur and the work of the Harvard Business School, 1980-1995. Boston: Harvard Business School Press. 
Strobl, A., Kronenberg, C., \& Peters, M. (2012). Entrepreneurial attitudes and intentions: Assessing gender specific differences. International Journal of Entrepreneurship and Small Business, 15(4), 452-468.

Strohmeyer, R., \& Tonoyan, V. (2005). Bridging the gender gap in employment growth: On the role of innovativeness and occupational segregation. The International Journal of Entrepreneurship and Innovation, 6(4), 259-273.

Tamizharasi, G., \& Panchanatham, N. (2010). An empirical study of demographic variables on entrepreneurial attitudes. International Journal of Trade, Economics and Finance, 1, 215-220.

The Overseas Development Institute (ODI). (2012). Youth business international: Youth entrepreneurship support on different contexts. URL: http://www.odi.org/projects/youth-business-international-youth-entrepreneurship-supportdifferent-contexts. Accessed 3 Oct 2016.

The Times of India. 2016. Tamil Nadu among top 5 choices for student migrants. 4 December 2016: http://timesofindia. indiatimes.com/city/chennai/tamil-nadu-among-top-5-choices-for-student-migrants/articleshow/55785590.cms. Accessed 2 Dec 2016

Tosun, J., Jensen, C., Speckesser, S., O'Reilly, J. (2017). The absorption of structural and investment funds and youth unemployment: An empirical test. In: Peter Berkowitz, John Bachtler, Tatjana Muravska \& Sally Hardy (eds), The contribution of cohesion policy to smart, sustainable and inclusive growth. London: Routledge. http://www. tandfebooks.com/doi/view/10.4324/9781315401867.

United Nations. (2013). Opportunities and constraints to youth entrepreneurship: Perspectives of youth entrepreneurs in Swaziland. URL: http://www.sz.undp.org/content/dam/swaziland/docs/documents/UNDP_SZ_ OpportunitiesAndConstraintsToYouthEntrepreneurship2013.pdf. Accessed 3 Oct 2016.

Veciano, J. M., Aponte, M., \& Urbano, D. (2005). University students' attitudes towards entrepreneurship: A tri-country study. International entrepreneurship and management, 1(2), 165-182.

Warmuth, J., Kittel, B., Steiber, N., \& Mühlböck, M. (2014). CUPESSE theoretical overview. www.cupesse.eu. Accessed 5 Oct 2016.

Williams, R. M. (1968). Values. In E. Sills (Ed.), International encyclopedia of the social sciences (pp. 203-207). New York: Macmillan.

Wilson, F., Kickul, J., \& Marlino, D. (2007). Gender, entrepreneurial self-efficacy, and entrepreneurial career intentions: Implications for entrepreneurship education. Entrepreneurship Theory and Practice, 31(3), 387-406.

World Bank, (2008). Children and the youth, Volume II, Number 6.

Wright, T. L., \& Tedeschi, R. G. (1975). Factor analysis of the interpersonal trust scale. Journal of Consulting and Clinical Psychology, 43, 470-477.

Yordanova, D. I., \& Tarrazon, M. A. (2010). Gender differences in entrepreneurial intentions: Evidence from Bulgaria. Journal of Developmental Entrepreneurship, 15(3), 245-261.

Zeffane, R. (2013). Gender and youth entrepreneurial potential: Evidence from the United Arab Emirates. International Journal of Business and Management, 8(1), 60-72.

Submit your manuscript to a SpringerOpen ${ }^{\circ}$ journal and benefit from:

- Convenient online submission

- Rigorous peer review

Open access: articles freely available online

High visibility within the field

Retaining the copyright to your article

Submit your next manuscript at $>$ springeropen.com 